\title{
Model Transportasi Pengiriman Ikan Segar untuk Industri Pengolahan Ikan (Studi Kasus Industri Surimi di Jawa Tengah)
}

\author{
Margie Wiendy Christianingrum, Murdjito, dan Hasan Iqbal Nur \\ Departemen Teknik Sipil, Institut Teknologi Sepuluh Nopember (ITS) \\ Corresponding Author: hasaniqbaln@gmail.com
}

\begin{tabular}{|c|c|}
\hline ARTIKEL INFO & ABSTRAK \\
\hline $\begin{array}{l}\text { Kata Kunci } \\
\text { Optimasi, Kapal Pengangkut Ikan, } \\
\text { Kebijakan Cantrang, Surimi. }\end{array}$ & $\begin{array}{l}\text { Kebijakan yang telah dikeluarkan pemerintah melalui Peraturan Menteri } \\
\text { Kelautan dan Perikanan KP No } 2 \text { tahun } 2015 \text { tentang larangan } \\
\text { penggunaan alat penangkapan ikan pukat hela (trawls) dan pukat tarik } \\
\text { (seine nets), tak hanya berdampak pada nelayan, namun juga berdampak } \\
\text { pada industri surimi, terutama industri surimi yang berada di Jawa } \\
\text { Tengah. Lebih dari } 80 \% \text { pabrik surimi tidak beroperasi lagi karena } \\
\text { kesulitan mendapatkan bahan baku (ikan demersal). Tujuan dari } \\
\text { penelitian ini adalah untuk menentukan model logistik pengangkutan ikan } \\
\text { bahan baku surimi yang optimum dari masing-masing opsi lokasi } \\
\text { pemasok dengan menggunakan bahan baku ikan alternatif. Metode yang } \\
\text { digunakan dalam penelitian ini adalah metode optimasi. Dari hasil } \\
\text { analisis yang telah dilakukan bahan baku alternatif pengganti yang akan } \\
\text { digunakan adalah ikan tenggiri, ikan kakap merah, ikan tigawaja dan ikan } \\
\text { beloso. Alat angkut yang digunakan adalah kapal pengangkut ikan. Dari } \\
\text { proses optimasi, skenario pengiriman melalui titik hub PPS Kendari } \\
\text { memiliki biaya satuan yang paling minimum yakni Rp. } 2,686 \text { per kg. } 5 \\
\text { rute yang terpilih dalam model tersebut antara lain, Rute } 1 \text { PPN Sungai } \\
\text { Liat - PPP Tasik Agung dengan kargo ikan terkirim } 13.389 \text { ton/tahun, } \\
\text { Rute } 3 \text { PPS Kendari - PPP Tasik Agung (16.750 ton/tahun), Rute } 4 \text { PPS } \\
\text { Kendari - PPN Pekalongan (16.848 ton/tahun), Rute } 5 \text { PPN Ambon - } \\
\text { PPS Kendari (21.570 ton/tahun), dan Rute } 7 \text { PPI Likupang - PPS Kendari } \\
\text { (6.131 ton/tahun). Penambahan biaya transportasi akan menambah biaya } \\
\text { produksi sebesar } 15 \% \text {. }\end{array}$ \\
\hline
\end{tabular}

\section{PENDAHULUAN}

Indonesia dalah negara kepulauan terbesar di dunia, yang memiliki potensi sumberdaya pada sektor kelautan dan perikanan yang sangat melimpah. Pada tahun 2017, potensi lestari sumber daya ikan atau maximum sustainable yield (MSY) di perairan laut Indonesia sebesar 12,54 juta ton, mengalami kenaikan $25 \%$ dari tahun sebelumnya yakni 9,93 juta ton [1]. Namun demikian, telah terjadi ketidakseimbangan tingkat pemanfaatan sumber daya perikanan antar wilayah tangkapan dan antar jenis sumber daya. Sesuai dengan yang tercantum dalam Keputusan Menteri Kelautan dan Perikanan Republik Indonesia nomor 47 Tahun 2016, di sebagian wilayah telah terjadi gejala tangkap lebih (overfishing) seperti di Laut Jawa dan Selat Malaka, sedangkan di sebagian besar wilayah timur tingkat pemanfaatannya masih di bawah potensi lestari.

Sebagai salahsatu bentuk upaya menjaga kelestarian dan ketersediaan sumberdaya ikan yang berada di wilayah perairan Indonesia, pemerintah telah mengeluarkan Peraturan Menteri Kelautan dan Perikanan KP No 2 tahun 2015 tentang larangan penggunaan alat penangkapan ikan pukat hela (trawls) dan pukat tarik (seine nets). Kebijakan pelarangan cantrang tersebut berdampak besar untuk nelayan yang beroperasi di pantai utara Jawa. Namun, dampak dari kebijakan tidak hanya dirasakan oleh para nelayan, namun juga oleh para pelaku industri surimi.

Surimi adalah lumatan daging ikan yang telah diproses dengan cara tertentu (antara lain pencucian, pengepresan, dan penambahan garam, dll), berwarna putih dan rasanya tawar. Umumnya bahan baku dari surimi adalah ikan demersal, yang merupakan salahsatu hasil tangkapan cantrang. Beberapa jenis ikan demersal yang digunakan sebagai bahan baku surimi adalah gulamah, beloso, kurisi, ekor kuning, kerong-kerong, kuro, biji nangka, kuniran, dan swanggi [2].

Seluruh industri surimi berlokasi di Pulau Jawa, sehingga pemasok bahan baku surimi merupakan nelayan cantrang dengan daerah penangkapan WPP RI 712 (Laut Jawa). Semenjak pelarangan alat tangkap cantrang resmi diberlakukan, banyak pabrik surimi yang tidak beroperasi lagi karena kesulitan mendapatkan bahan baku.

Untuk menangani permasalahan tersebut, Kementrian Kelautan dan Perikanan (KKP) menawarkan solusi kepada para pelaku industri surimi, yakni melakukan 
diversifikasi produk dengan menggunakan alternatif bahan baku (mengganti jenis ikan demersal dengan ikan lain, mengubah komposisi bahan baku untuk produk surimi tertentu) yang ditangkap dari perairan selain WPP RI 712 [2]. Pada penelitian ini, akan dilakukan analisis pengiriman ikan yang sesuai dengan karakteristik bahan baku surimi dan dengan biaya pengiriman yang paling minimum, sehingga permintaan kebutuhan bahan baku industri surimi dapat terpenuhi.

\section{TINJAUAN PUSTAKA}

\section{A. Surimi}

Surimi didefinisikan sebagai bentuk cincangan daging ikan yang mengalami proses penghilangan tulang (deboning), pencucian dan penghilangan sebagian air (dewatering) sehingga dikenal sebagai protein konsentrat basah (wet concentrate protein) dari daging ikan [3].

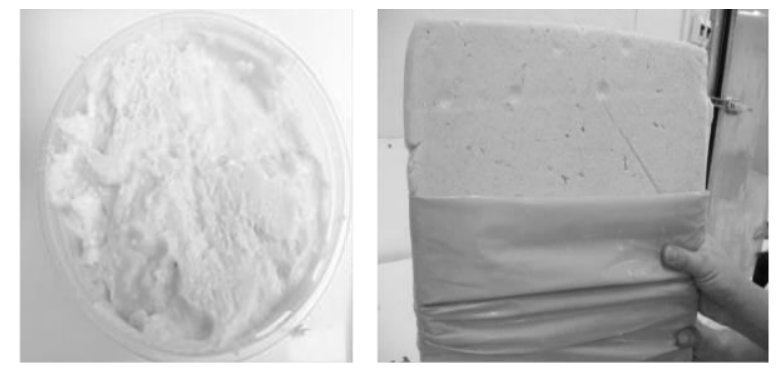

Gambar 1. Hasil Olahan Surimi dalam Bentuk Pasta dan Beku.

Karakteristik untuk bahan baku surimi adalah ikan berkadar lemak rendah dengan konsistensi daging yang padat dan kandungan protein yang tinggi agar dihasilkan surimi dengan sifat gel yang baik. Sedangkan di Indonesia, produk surimi banyak menggunakan ikan demersal sebagai bahan baku utama. Ikan demersal memiliki kualitas yang baik sebagai bahan baku surimi karena karena memiliki daging putih dan tingkat kekenyalan daging yang baik. Jenis-jenis ikan demersal yang dominan digunakan sebagai bahan baku antara lain adalah gulamah, beloso, kurisi, kerong-kerong, biji nangka, kuniran, kapasan, remang, swanggi, dan lencam. Faktor utama yang menentukan mutu surimi adalah kesegaran ikan yang akan diolah [2].

\section{B. Kesegaran Ikan}

Ikan segar adalah ikan yang mempunyai sifat sama seperti ikan hidup, baik rupa, bau, rasa, maupun teksturnya [4]. Faktor yang menentukan mutu ikan segar adalah penanganan ikan sejak ditangkap hingga ikan sampai ke konsumen. Penanganan yang buruk akan menyebabkan ikan mengalami kebusukan sehingga tidak dapat dikonsumsi lagi.

Pendinginan merupakan perlakuan yang paling umum dalam mempertahankan mutu hasil perikanan terutama dalam tahap penanganan. Dalam penanganan ikan segar di upayakan suhu tetap rendah mendekati $0^{\circ} \mathrm{C}$. Prinsip proses pendinginan dan pembekuan adalah mengurangi atau menginaktifkan enzim dan bakteri pembusuk dalam tubuh ikan. Pada suhu $15-20^{\circ} \mathrm{C}$, ikan dapat disimpan hingga sekitar dua hari, pada suhu $5^{\circ} \mathrm{C}$ tahan selama 5-6 hari, sedangkan pada suhu $0^{\circ} \mathrm{C}$ dapat mencapai 9-14 hari [5].

\section{METODOLOGI PENELITIAN}

Berikut adalah alur pengerjaan dalam penelitian ini:

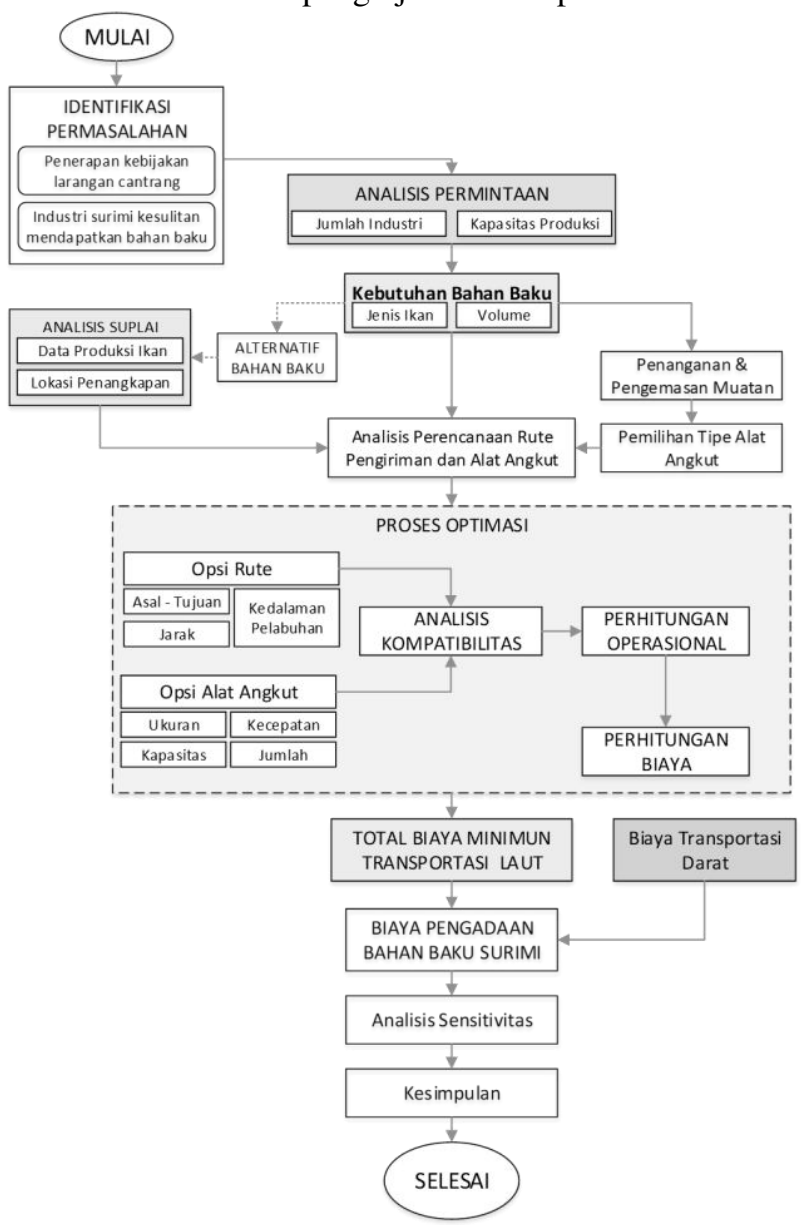

Gambar 2. Diagram alir penelitian.

\section{A. Tahap Identifikasi Permasalahan}

Pada tahap ini dilakukan identifikasi permasalahan terhadap kondisi eksisting. Permasalahan yang timbul adalah setelah diberlakukannya kebijakan pelarangan cantrang, industri surimi kesulitan untuk mendapatkan bahan baku surimi. Dikarenakan bahan baku surimi, yakni ikan demersal, merupakah salahsatu jenis ikan yang mendominasi hasil tangkapan cantrang.

\section{B. Tahap Analisis Permintaan dan Produksi Bahan Baku}

Dalam tahap ini, dilakukan identifikasi persebaran dan jumlah industri surimi di Jawa Tengah. Setelah itu dilakukan pemilihan terhadap beberapa pabrik surimi yang akan menjadi studi kasus dalam perhitungan ini. Selain itu, analisis juga dilakukan untuk mengetahui karakteristik ikan seperti apa yang dibutuhkan. Setelah mengetahui karakteristik dari kebutuhan bahan baku surimi eksisting, lalu dilakukan analisis untuk memilih bahan baku alternatif yang sesuai dengan karakteristik yang diminta (sesuai dengan solusi yang diarahkan oleh Kementerian, Kelautan dan Perikanan).

Setelah mengetahui ikan jenis apa yang akan dikirim, lalu dilakukan analisis untuk menentukan wilayah mana yang memiliki produksi lebih untuk memasok bahan baku surimi di Jawa Tengah, dan berapa pasokan yang bisa dikirim. Data produksi ikan didapatkan dari Data Statistik Direktorat Jenderal Perikanan Tangkap. 


\section{Tahap Optimasi}

Dalam analisis ini dilakukan identifikasi opsi rute (penentuan skenario pengiriman), meliputi titik asal dan tujuan, jarak tempuh antar titik, dan kedalaman pelabuhan bongkar. Selain dilakukan identifikasi opsi rute, dilakukan pula identifikasi opsi alat angkut. Tahap berikutnya adalah analisis kompabilitas, dilakukan untuk menyesuaikan kedalaman pelabuhan dengan sarat kapal dan membatasi waktu berlayar untuk rute mana saja yang melewati batas kesegaran ikan ( 9 hari).

Setelah itu, dilakukan perhitungan operasional untuk masing-masing rute pelayaran. Perhitungan meliputi perhitungan waktu (waktu berlayar, waktu berlabuh, waktu lamanya bongkar muat, waktu transhipment, dan komponen waktu lainnya seperti idle time, approaching time, waiting time), serta perhitungan biaya transportasi laut minimum (meliputi biaya kapital, biaya operasional, biaya perjalanan, dan biaya kepelabuhanan).

Proses optimisasi dilakukan dengan menjadikan frekuensi sebagai variable penentu (DV). Hasil dari proses optimisasi adalah terpilihnya rute-rute tertentu dan opsi kapal mana yang terpilh untuk melayani rute tersebut.

\section{Biaya Transportasi Darat}

Biaya transportasi darat dalam perhitungan ini meliputi biaya pengiriman muatan dari pelabuhan bongkar menuju industri. Dalam tahap ini ditentukan jenis dan spesifikasi alat angkut darat apa yang akan digunakan.

\section{E. Biaya Pengadaan Bahan Baku Surimi}

Pada tahap ini akan dibandingkan skenario model pengiriman mana yang memiliki biaya satuan pengiriman paling murah. Selain itu juga dilakukan analisis mengenai pengaruh biaya transportasi terhadap biaya produksi surimi.

\section{F. Tahap Analisis Sensitivitas}

Setelah hasil analisis didapatkan, langkah selanjutnya adalah melakukan analisis sensitivitas. Analisis ini dilakukan untuk mengetahui seberapa sensitif faktor kematian ikan pada saat pengiriman terhadap biaya satuan.

\section{G. Tahap Kesimpulan dan Saran}

Pada tahap ini hasil analisi dirangkum dan saran untuk pemerintah, serta pengembangan penelitian lebih lanjut.

\section{GAMBARAN UMUM}

\section{A. Industri Surimi}

UPI surimi berjumlah 14 UPI dan semua berlokasi di Jawa dengan rincian 7 UPI berada di Jawa Tengah, 1 UPI berada di Jawa Barat, dan 6 UPI lain berlokasi di Jawa Tengah. UPI produk berbahan baku surimi berjumlah 11 UPI. Untuk UPI fish jelly dan minced fish berjumlah 30 UPI dan tersebar ke seluruh Indonesia [6]. Jawa Tengah menjadi wilayah yang mendominasi UPI surimi di Indonesia.

Dari 9 UPI yang ada di Jawa Tengah, UPI yang akan menjadi studi kasus dalam penelitian ini adalah PT. Holi Mina Jaya (Rembang), CV. Sinar Mutiara Abadi (Rembang), PT. Bintang Karya Laut (Rembang), PT.
Sinar Bahari Agung (Kendal), dan PT. Blue Sea Industry (Pekalongan). Berikut adalah peta sebaran ke-5 (lima) UPI tersebut:

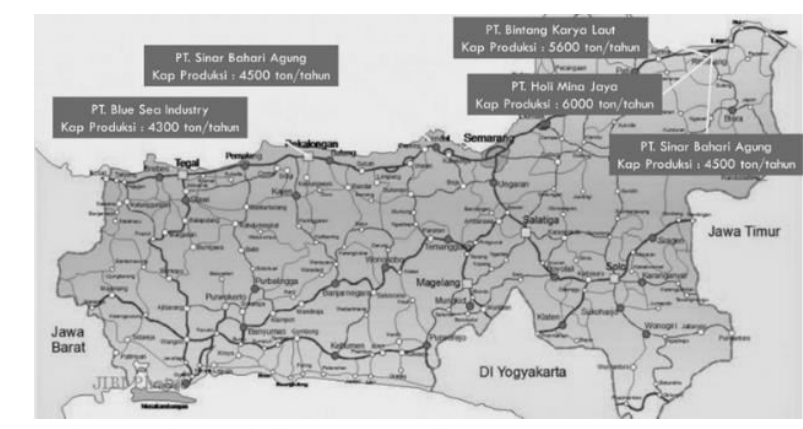

Gambar 3. Sebaran 5 (lima) UPI Studi Kasus.

\section{B. Bahan Baku Surimi}

Rata-rata nelayan Jawa Tengah melaut atau menangkap ikan demersal (bahan baku surimi) di WPP 712 (Laut Jawa) dengan menggunakan cantrang. Hal ini sudah terjadi selama bertahun-tahun, sehingga pada akhirnya status WPP 712 untuk komoditas ikan demersal meningkat menjadi fully exploited.

Tabel 1. Tabel Pemanfaatan Ikan Demersal di Tiap WPP

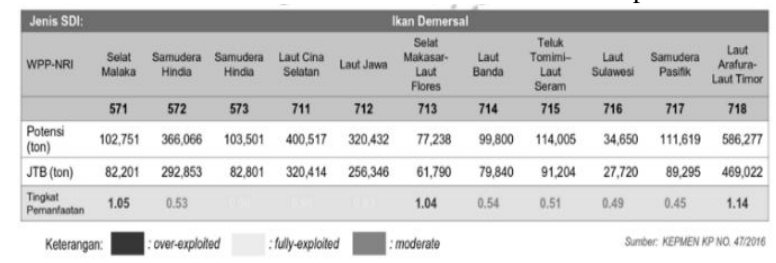

Sebagai pengganti ikan demersal, terdapat beberapa jenis ikan lain yang mempunyai karakteristik yang cocok untuk menjadi alternatif bahan baku surimi. Beberapa jenis ikan tropik dengan kualitas yang bagus adalah tenggiri, kakap, dan cucut. Sedangkan untuk ikan tawar, jenis-jenis seperti lele dumbo, tawes, dan nila memiliki kualitas yang cukup bagus untuk diolah menjadi surimi [2].

Dari opsi alternatif bahan baku yang ada, daging ikan cucut yang mengandung urea kadar tinggi sehingga menyebabkan daging cucut cenderung berbau dan akan merusak kualitas surimi. Sedangkan untuk ikan tawar lele dumbo, tawes, dan nila akan lebih sulit untuk mendapatkan pasar baru (satu-satunya negara yang sudah mulai beralih menggunakan bahan baku ikan tawar adalah China). Opsi ikan yang memungkinkan untuk dijadikan alternatif bahan baku surimi adalah ikan tenggiri dan ikan kakap. Berikut adalah proyeksi produksi tahun 2018 untuk Ikan Tenggiri dan Ikan Kakap di Indonesia: 


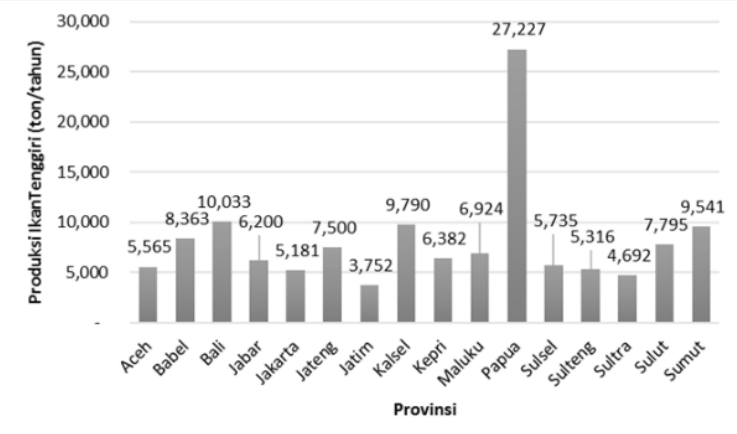

Gambar 4. Produksi ikan tenggiri di Indonesia.

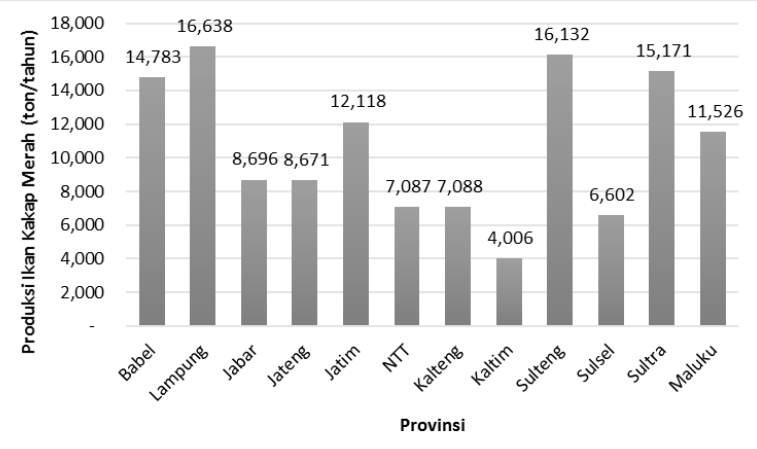

Gambar 5. Produksi ikan kakap merah di Indonesia.

Namun jumlah ikan tenggiri dan kakap merah belum cukup untuk memenuhi kebutuhan bahan baku dari 5 (lima) UPI yang dijadikan studi kasus. Maka dalam penelitian ini, produksi ikan bahan baku surimi saat ini akan tetap diperhitungkan. Jenis ikan bahan baku surimi yang masih akan digunakan adalah ikan tigawaja dan beloso. Berikut adalah proyeksi produksi tahun 2018 untuk Ikan Beloso dan Ikan Tigawaja di Indonesia:

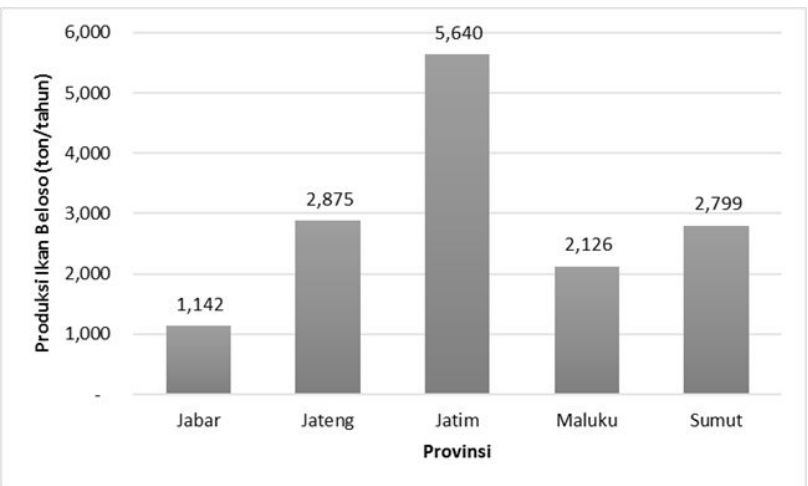

Gambar 6. Produksi Ikan Beloso.

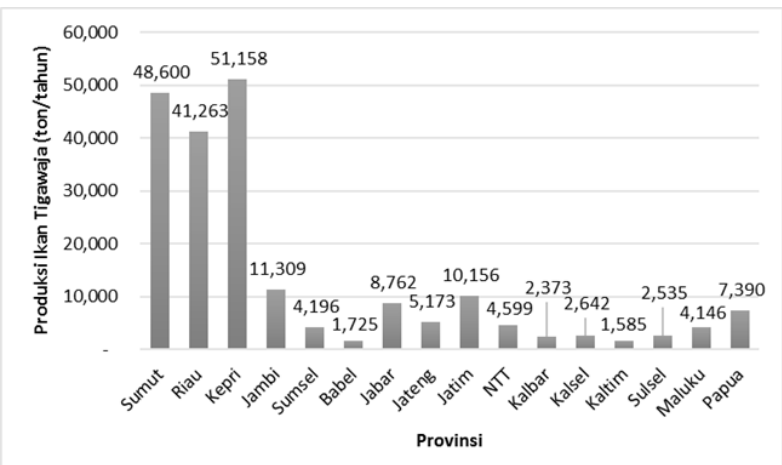

Gambar 7. Produksi Ikan Tigawaja.

\section{B. Kapal Penangkut Ikan}

Pada penelitian ini, alat angkut yang paling memungkinkan untuk melakukan pengiriman sesuai dengan permintaan adalah kapal pengangkut ikan. Kapal pengangkut ikan adalah kapal yang digunakan untuk mengangkut hasil perikanan dari kapal induk atau kapal penangkap ikan dari daerah penangkapan ke pelabuhan.

Untuk mendapatkan muatan saat di laut, kapal pengangkut tidak pelu menunggu, namun sudah melakukan perjanjian dengan kapal penangkap ikan. Sistem alih muat yang digunakan adalah system transhipment. Berikut skema pola operasi dari kapal pengangkut ikan eksisting:

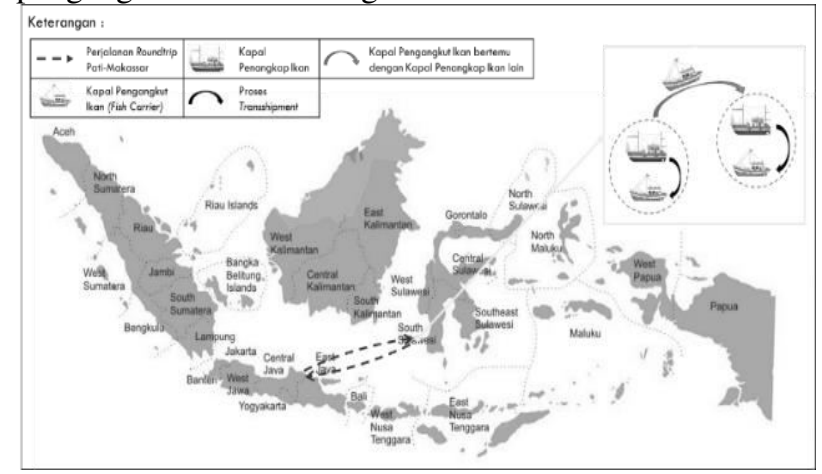

Gambar 8. Pola Operasi Transshipment Kapal Eksisting di Indonesia.

\section{Aturan Transhipment}

Sebagai bentuk upaya pemberantasan IUU Fishing, pemerintah Indonesia kembali mengeluarkan kebijakan terkait transshipment. Kebijakan tersebut dituangkan dalam Permen KP no 57 Tahun 2014, yang berisi:

1. Kapal pengangkut harus kembali dilakukan verifikasi dan terdaftar di Kementerian Kelautan dan Perikanan (KKP).

2. Kapal pengangkut wajib mengaktifkan VMS atau Vessel Monitoring Systems

3. Harus ada observer lokal yang naik dan mengawasi kapal

4. KKP akan menetukan kordinat lokasi operasional kapal

5. Hanya ikan jenis tertentu yang boleh dilakukan transshipment

6. Menentukan titik check in dan check out dalam upaya pemeriksaan kapal

\section{ANALISIS DAN PEMBAHASAN}

\section{A. Permintaan Ikan Bahan Baku Surimi}

Berikut adalah besar permintaan per tahun dari masingmasing pabrik (UPI) terpilih:

Tabel 2. Besar Permintaan yang Dibutuhkan UPI

\begin{tabular}{llccc}
\multicolumn{1}{c}{ Nama Perusahaan } & \multicolumn{1}{c}{ Lokasi } & $\begin{array}{c}\text { Kap. Produksi } \\
\text { (ton/tahun) }\end{array}$ & $\begin{array}{c}\text { Asumsi Produksi } \\
\text { (ton/tahun) }\end{array}$ & $\begin{array}{c}\text { Keb. Bahan Baku } \\
\text { (ton/tahun) }\end{array}$ \\
\hline \hline PT. Bintang Karya Laut & Rembang & 5,600 & 3,360 & 10,483 \\
\hline CV. Sinar Mutiara Abadi & Rembang & 4,500 & 2,700 & 8,424 \\
\hline PT. Holi Mina Jaya & Rembang & 6,000 & 3,600 & 11,232 \\
\hline PT. Blue Sea Industry & Pekalongan & 4,500 & 2,700 & 8,424 \\
\hline PT. Sinar Bahari Agung & Kendal & 4,500 & 2,700 & 8,424 \\
\hline
\end{tabular}

Dalam analisis diatas, diasumsikan utilitas produksi adalah sebesar $60 \%$. Dan perbandingan hasil produksi dengan kebutuhan bahan baku adalah 1:3,12 [7]. Dari tabel di atas, besar kebutuhan bahan baku dikelompokkan kembali berdasarkan wilayahnya, untuk memudahkan 
analisis. Berikut adalah kebutuhan bahan baku berdasarkan wilayahnya:

Tabel 3. Besar Permintaan UPI Per Wilayah

\begin{tabular}{lcc}
\multicolumn{1}{c}{ Lokasi Perusahaan } & $\begin{array}{c}\text { Asumsi Produksi } \\
\text { (ton/tahun) }\end{array}$ & $\begin{array}{c}\text { Keb. Bahan Baku } \\
\text { (ton/tahun) }\end{array}$ \\
\hline \hline Rembang & 9,660 & 30,139 \\
\hline Kendal & 2,700 & 8,424 \\
\hline Pekalongan & 2,700 & 8,424 \\
\hline Total Demand & & $\mathbf{4 6 , 9 8 7}$ \\
\hline
\end{tabular}

Setelah menentukan kelima UPI yang menjadi studi kasus, lalu dianalisis pelabuhan perikanan mana di wilayah tersebut yang memungkinkan atau layak untuk disinggahi. Faktor utama yang menentukan kelayakan adalah jarak UPI dengan pelabuhan, kedalaman pelabuhan tersebut dan tipe pelabuhannya. Dari faktor tersebut terpilih PPP Tasik Agung (pelabuhan bongkar untuk UPI wilayah Rembang) dan PPN Pekalongan (spelabuhan bongkar untuk UPI wilayah Kendal dan Pekalongan).

\section{B. Produksi Ikan Bahan Baku Surimi}

Data produksi ikan didapatkan dari Direktorat Jenderal Perikanan Tangkap KKP untuk tahun 2012-2016. Sedangkan, data yang akan digunakan adalah data produksi ikan tahun 2018. Untuk mendapatkan data produksi tahun 2018, digunakan laju pertumbuhan dari masing-masing jenis ikan per wilayahnya. Dari data produksi per jenis ikan tersebut, data dikelompokkan berdasarkan wilayahnya atau provinsinya. Data produksi tersebut lalu dikurangkan dengan angka konsumsi ikan untuk provinsi tersebut. Berikut adalah wilayah yang akan menjadi titik suplai:

Tabel 4. Wilayah Serta Besar Suplai yang Tersedia

\begin{tabular}{lc}
\multicolumn{1}{c}{ Nama Provinsi } & Supply(ton) \\
\hline \hline Babel & 13,389 \\
\hline Sulteng & 6,723 \\
\hline Sultra & 5,898 \\
\hline Sulut & 15,285 \\
\hline Maluku & $\mathbf{2 1 , 5 7 0}$ \\
\hline Papua & 6,711 \\
\hline Total & $\mathbf{6 9 , 5 7 5}$ \\
\hline
\end{tabular}

\section{Alternatif Alat Angkut}

Sebelum menentukan penggunaan kapal pengangkut ikan, telah dilakukan analisis untuk mempertimbangkan jenis alat angkut apa saja yang memungkinkan untuk digunakan. Berikut adalah opsi dan pertimbangan pemilihan alat angkut:

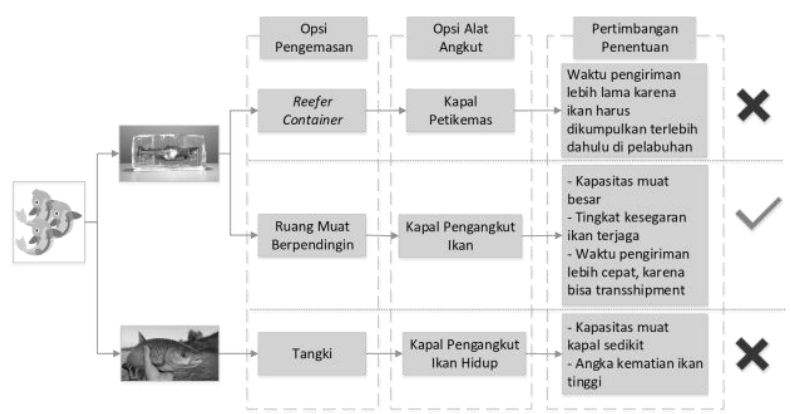

Gambar 9. Pertimbangan Pemilihan Alat Angkut.

Opsi ukuran alat angkut didapatkan dari hasil regresi kapal pembanding. Berikut adalah alternatif alat angkut:

\begin{tabular}{|c|c|c|c|c|c|c|}
\hline \multirow[t]{2}{*}{ Item } & \multirow[t]{2}{*}{ Satuan } & \multicolumn{5}{|c|}{ Alternatif Alat Angkut } \\
\hline & & Kapal 1 & Kapal 2 & Kapal 3 & Kapal 4 & Kapal 5 \\
\hline \multicolumn{7}{|l|}{ Ukuran Utama } \\
\hline Gross Tonnage & ton & 100 & 200 & 300 & 400 & 500 \\
\hline Panjang (LOA) & $m$ & 32.2 & 33.9 & 35.7 & 37.4 & 39.1 \\
\hline Lebar (B) & $m$ & 8.0 & 8.3 & 8.5 & 8.8 & 9.1 \\
\hline Sarat (T) & $m$ & 3.1 & 3.2 & 3.3 & 3.5 & 3.6 \\
\hline \multicolumn{7}{|l|}{ Permesinan } \\
\hline Mesin Utama & $\mathrm{KwH}$ & 563 & 650 & 738 & 825 & 912 \\
\hline SFOC Mesin Utama & $g / K w H$ & 195 & 195 & 188 & 188 & 189 \\
\hline Mesin Bantu & $\mathrm{KwH}$ & 315 & 419 & 522 & 625 & 729 \\
\hline SFOC Mesin Bantu & $g / K w H$ & 210 & 209 & 208 & 209 & 204 \\
\hline Kapasitas Muat & ton & 183 & 242 & 301 & 360 & 419 \\
\hline \multicolumn{7}{|l|}{ Kecepatan } \\
\hline Asal - Tujuan & knot & 9.0 & 8.8 & 9.3 & 9.7 & 11.6 \\
\hline Tujuan-Asal & knot & 10.4 & 10.1 & 10.7 & 11.2 & 13.3 \\
\hline \multicolumn{7}{|l|}{ Alat Bongkar Muat } \\
\hline Jumlah Alat & unit & 0 & 1 & 1 & 2 & 2 \\
\hline Produktivitas & tonjam/umit & 0 & 0 & 25 & 25 & 25 \\
\hline Harga Kapal & $U S D / G T$ & $1,433.2$ & $1,968.1$ & $3,152.5$ & $3,152.5$ & $3,152.5$ \\
\hline
\end{tabular}

Dalam penelitian ini, analisis mengenai alat angkut dibatasi pada perhitungan operasional saja, sehingga tidak dilakukan perhitungan teknis seperti perhitungan hambatan, stabilitas dll.

\section{Perencanaan Rute Pengiriman}

Berikut adalah skema titik permintaan dan titik suplai dalam penelitian ini.

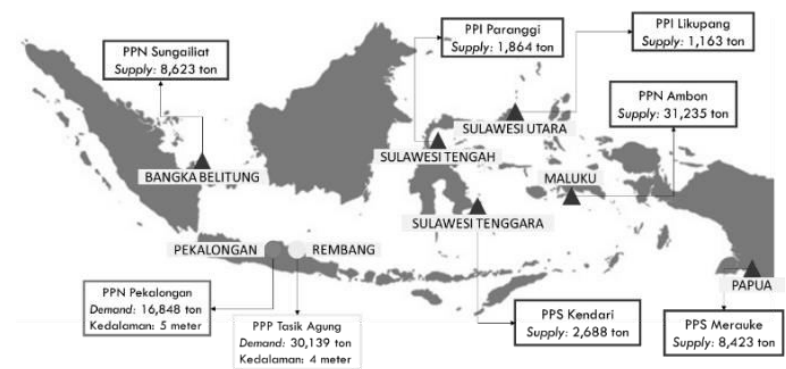

Gambar 10. Perencanaan Rute Pengiriman.

Dalam analisis ini, titik pelabuhan muat tidak dijadikan tempat singgah namun dijadikan sebagai patokan titik temu antara kapal penangkap ikan dan kapal pengangkut ikan. Ikan yang akan dikirim, akan dimuat dengan sistem transshipment ship-to-ship antara kapal penangkap ikan dan kapal pengangkut ikan. Sehingga, pemuatan ikan tidak dilakukan di pelabuhan.

Direncanakan ada 3 (tiga) opsi skenario pengiriman yang akan dianalisis dalam penelitian ini. 3 (tiga) opsi pengiriman tersebut adalah:

a. Skenario Pengiriman Langsung (Direct)

b. Skenario Pengiriman Melalui Titik Hub PPS Kendari

c. Skenario Pengiriman Melalui Titik Hub PPN Ambon

PPS Kendari dipilih karena memiliki lokasi yang paling strategis dan relatif dekat dengan titik permintaan. PPN Ambon dipilih karena memiliki jumlah produksi yang paling besar diantara titik suplai yang lain. 3 (tiga) opsi skenario tersebut lalu dibandingkan dan dipilih berdasarkan biaya satuan paling rendah

\section{E. Analisis Kompatibilitas}

Analisis kompatibilitas sarat kapal dengan kedalaman pelabuhan dilakukan untuk memastikan alternatif kapal mana saja yang nantinya bisa atau tidak bisa sandar di pelabuhan bongkarnya. Analisis dilakukan dengan membandingkan sarat dari semua opsi kapal dengan kedalaman pelabuhan bongkar di semua rute. 
Berikut adalah hasil analisis kompatibilitas sarat kapal dengan kedalaman pelabuhan untuk semua rute:

Tabel 6. Analisis Kompatibilitas Sarat Kapal dengan Pelabuhan

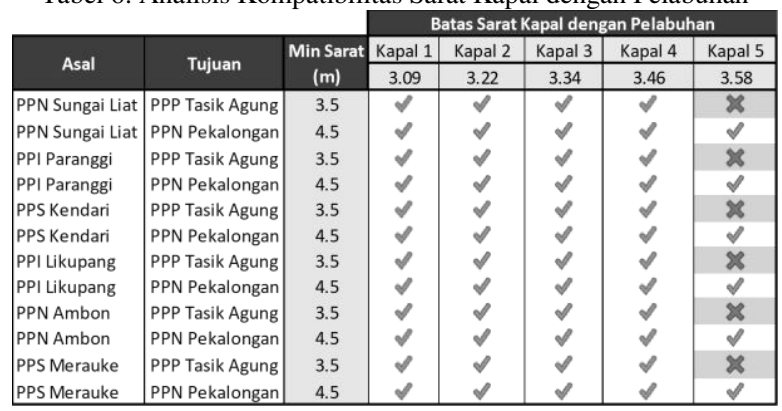

Dan berikut adalah analisis kompatibilitas waktu berlayar dengan kesegaran ikan. Batasan ini menjaga kesegaran ikan. Dalam perhitungan ini, batasan yang digunakan adalah 9 hari, dengan asumsi 5 hari sisanya adalah lama maksimal penyimpanan ikan di pabrik. Berikut adalah hasil analisis kompatibilitas untuk skenario model pengiriman langsung.

Tabel 7. Kompatibilitas Waktu Berlayar dengan

\begin{tabular}{|c|c|c|c|c|c|c|c|}
\hline \multirow{2}{*}{ Rute } & \multirow{2}{*}{ Asal } & \multirow{2}{*}{ Tujuan } & \multicolumn{5}{|c|}{ Batasan Waktu Berlayar Asal-Tujuan } \\
\hline & & & Kapal 1 & Kapal 2 & Kapal 3 & Kapal 4 & Kapal 5 \\
\hline Rute 1 & PPN Sungai Liat & PPP Tasik Agung & $\checkmark$ & $\checkmark$ & $\checkmark$ & $\checkmark$ & $\checkmark$ \\
\hline Rute 2 & PPN Sungai Liat & PPN Pekalongan & $\downarrow$ & 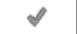 & $\downarrow$ & $\checkmark$ & $\checkmark$ \\
\hline Rute 3 & PPI Paranggi & PPP Tasik Agung & $\checkmark$ & $\downarrow$ & $\downarrow$ & $\downarrow$ & $\checkmark$ \\
\hline Rute 4 & PPI Paranggi & PPN Pekalongan & $\checkmark$ & $\downarrow$ & $\downarrow$ & $\checkmark$ & $\checkmark$ \\
\hline Rute 5 & PPS Kendari & PPP Tasik Agung & $\downarrow$ & $\downarrow$ & $\downarrow$ & $\checkmark$ & $\checkmark$ \\
\hline Rute 6 & PPS Kendari & PPN Pekalongan & $\downarrow$ & $\downarrow$ & $\downarrow$ & $\checkmark$ & $\checkmark$ \\
\hline Rute 7 & PPI Likupang & PPP Tasik Agung & $\checkmark$ & $\checkmark$ & $\downarrow$ & $\checkmark$ & $\checkmark$ \\
\hline Rute 8 & PPI Likupang & PPN Pekalongan & $\checkmark$ & $\downarrow$ & $\downarrow$ & $\downarrow$ & $\checkmark$ \\
\hline Rute 9 & PPN Ambon & PPP Tasik Agung & $\checkmark$ & $\checkmark$ & $\checkmark$ & $\checkmark$ & $\checkmark$ \\
\hline Rute 10 & PPN Ambon & PPN Pekalongan & $\downarrow$ & $\downarrow$ & $\downarrow$ & $\checkmark$ & $\checkmark$ \\
\hline Rute 11 & PPS Merauke & PPP Tasik Agung & $\checkmark$ & $\downarrow$ & $\downarrow$ & $\checkmark$ & $\downarrow$ \\
\hline Rute 12 & PPS Merauke & PPN Pekalongan & $\checkmark$ & $\checkmark$ & $\checkmark$ & $\checkmark$ & $\checkmark$ \\
\hline
\end{tabular}

Untuk kedua model $h u b$, waktu 9 hari dibagi menjadi 2 bagian, yakni 4 hari dan 5 hari. 4 hari adalah batas kesegaran untuk pengiriman dari titik supply ke titik $h u b$ dan untuk pengiriman dari titik hub ke titik demand, batas kesegaran adalah 5 hari. Berikut adalah hasil analisis untuk pengiriman melalui titik hub.

Tabel 8. Kompatibilitas Waktu Berlayar-Kesegaran Ikan (Hub PPS Kendari)

\begin{tabular}{|c|c|c|c|c|c|c|c|}
\hline \multirow{2}{*}{ Rute } & \multirow{2}{*}{ Asal } & \multirow{2}{*}{ Tujuan } & \multicolumn{5}{|c|}{ Batasan Waktu Berlayar Asal-Tujuan } \\
\hline & & & Kapal 1 & Kapal 2 & Kapal 3 & Kapal 4 & Kapal 5 \\
\hline Rute 1 & PPN Sungai Liat & PPP Tasik Agung & $\checkmark$ & $\checkmark$ & $\checkmark$ & $\checkmark$ & $\checkmark$ \\
\hline Rute 2 & PPN Sungai Liat & PPN Pekalongan & $\checkmark$ & $\checkmark$ & 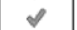 & $\checkmark$ & $\triangle$ \\
\hline Rute 3 & PPS Kendari & PPP Tasik Agung & $\downarrow$ & $\downarrow$ & $\downarrow$ & $\checkmark$ & $\downarrow$ \\
\hline Rute 4 & PPS Kendari & PPN Pekalongan & $x$ & $x$ & $x$ & $\triangle$ & $\checkmark$ \\
\hline Rute 5 & PPN Ambon & PPS Kendari & $\checkmark$ & $\checkmark$ & $\downarrow$ & $\triangle$ & $\triangle$ \\
\hline Rute 6 & PPI Paranggi & PPS Kendari & $\checkmark$ & $\checkmark$ & 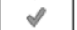 & 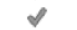 & $\triangle$ \\
\hline Rute 7 & PPI Likupang & PPS Kendari & $\downarrow$ & $\checkmark$ & $\triangle$ & $\triangle$ & $\triangle$ \\
\hline Rute 8 & PPS Merauke & PPS Kendari & $x$ & $x$ & $x$ & $x$ & $\Delta$ \\
\hline
\end{tabular}

Tabel 9. Kompatibilitas Waktu Berlayar-Kesegaran Ikan (Hub PPN Ambon)

\begin{tabular}{|c|c|c|c|c|c|c|c|}
\hline \multirow{2}{*}{ Rute } & \multirow{2}{*}{ Asal } & \multirow{2}{*}{ Tujuan } & \multicolumn{5}{|c|}{ Batasan Waktu Berlayar Asal-Tujuan } \\
\hline & & & Kapal 1 & Kapal 2 & Kapal 3 & Kapal 4 & Kapal 5 \\
\hline Rute 1 & PPN Sungai Liat & PPP Tasik Agung & $\checkmark$ & $\checkmark$ & $\checkmark$ & $\checkmark$ & $\checkmark$ \\
\hline Rute 2 & PPN Sungai Liat & PPN Pekalongan & $\checkmark$ & $\checkmark$ & $\checkmark$ & 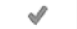 & $\checkmark$ \\
\hline Rute 3 & PPN Ambon & PPP Tasik Agung & $\downarrow$ & $x$ & 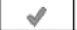 & $\downarrow$ & $\checkmark$ \\
\hline Rute 4 & PPN Ambon & PPN Pekalongan & $x$ & $x$ & $x$ & $x$ & 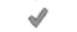 \\
\hline Rute 5 & PPS Kendari & PPN Ambon & $\downarrow$ & $\downarrow$ & $\checkmark$ & $\downarrow$ & $\downarrow$ \\
\hline Rute 6 & PPI Paranggi & PPN Ambon & $x$ & $x$ & $x$ & $\triangle$ & $\downarrow$ \\
\hline Rute 7 & PPI Likupang & PPN Ambon & $\downarrow$ & $x$ & $\downarrow$ & 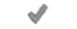 & $\downarrow$ \\
\hline Rute 8 & PPS Merauke & PPN Ambon & $\checkmark$ & $\checkmark$ & $\checkmark$ & $\checkmark$ & $\checkmark$ \\
\hline
\end{tabular}

\section{F. Hasil Optimasi}

1. Skenario Pengiriman Langsung (Direct)
Berikut adalah skema yang dihasilkan oleh optimasi untuk skenario pengiriman langsung (direct):

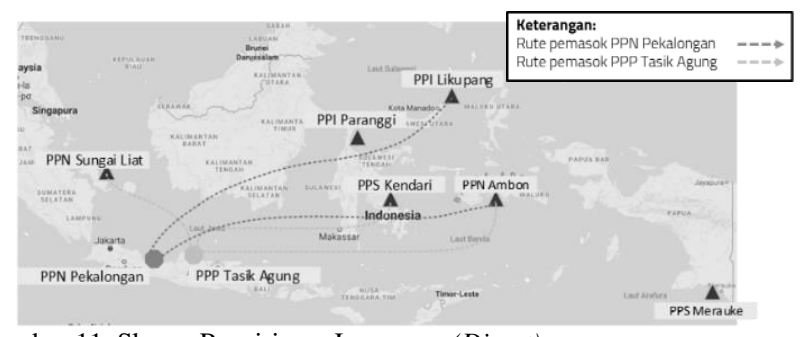

Gambar 11. Skema Pengiriman Langsung (Direct).

Untuk skenario pengiriman langsung, terdapat 5 (lima) rute yang terpilih, yakni Rute 1, Rute 5, Rute 8, Rute 9, dan Rute 10. Kapal yang akan digunakan untuk Rute 1 adalah Kapal 4 (400 GT) dengan payload 309 ton dengan jumlah 1 unit, Rute 5 juga dilayani oleh Kapal 4 dengan jumlah 1 unit, untuk Rute 8 dilayani oleh Kapal 5 (500 GT) dengan payload 359 ton dan jumlah 2 unit, Rute 9 menggunakan Kapal 4 dengan jumlah 2 unit dan Rute 10 menggunakan Kapal 5 dengan jumlah kapal 1 unit.

Tabel 10. Rute Terpilih Untuk Skenario Direct

\begin{tabular}{|c|l|c|c|c|c|}
\hline Rute & \multicolumn{1}{|c|}{ Asal } & Tujuan & $\begin{array}{c}\text { Jarak } \\
(\mathrm{nm})\end{array}$ & $\begin{array}{c}\text { Kargo Terkirim } \\
\text { (ton) }\end{array}$ & $\begin{array}{c}\text { Frekuensi } \\
\text { (per tahun) }\end{array}$ \\
\hline Rute 1 & PPN Sungai Liat & PPP Tasik Agung & 437 & 13,389 & 48 \\
Rute 5 & PPS Kendari & PPP Tasik Agung & 1,019 & 5,898 & 21 \\
Rute 8 & PPI Likupang & PPN Pekalongan & 1,413 & 15,285 & 47 \\
Rute 9 & PPN Ambon & PPP Tasik Agung & 1,068 & 10,852 & 39 \\
Rute 10 & PPN Ambon & PPN Pekalongan & 1,171 & 1,563 & 5 \\
\hline
\end{tabular}

Tabel 11. Kebutuhan Kapal Untuk Skenario Direct

\begin{tabular}{|c|c|c|c|}
\hline Rute & $\begin{array}{c}\text { Kapal } \\
\text { Terpilih }\end{array}$ & $\begin{array}{c}\text { Payload } \\
\text { (ton) }\end{array}$ & $\begin{array}{c}\text { Jumlah } \\
\text { (unit) }\end{array}$ \\
\hline Rute 1 & Kapal 4 & 309 & 1 \\
Rute 5 & Kapal 4 & 309 & 1 \\
Rute 8 & Kapal 5 & 359 & 2 \\
Rute 9 & Kapal 4 & 309 & 2 \\
Rute 10 & Kapal 5 & 359 & 1 \\
\hline
\end{tabular}

Dari hasil perhitungan waktu, diketahui bahwa Rute 8, yakni PPI Likupang - PPN Pekalongan memiliki total waktu terbesar, yakni 10.1 hari per roundtrip. Total waktu terbesar kedua adalah Rute 9 dengan kebutuhan roundtrip 9.1 hari, dengan rute PPN Ambon - PPP Tasik Agung. Total waktu terpendek adalah untuk Rute 1, yakni PPN Sungai Liat - PPP Tasik Agung, yakni 4.1 hari/roundtrip.

Tabel 12. Hasil Perhitungan Waktu Skenario Direct
\begin{tabular}{|c|c|c|}
\hline Rute & $\begin{array}{c}\text { Total Waktu } \\
\text { (hari/R.trip) }\end{array}$ & $\begin{array}{c}\text { Frekuensi Maksimal } \\
\text { (kali/tahun) }\end{array}$ \\
\hline Rute 1 & 4.1 & 73 \\
Rute 5 & 8.7 & 34 \\
Rute 8 & 10.1 & 29 \\
Rute 9 & 9.1 & 27 \\
Rute 10 & 8.5 & 29 \\
\hline
\end{tabular}

Dari keseluruhan biaya untuk masing-masing rute, total biaya yang timbul adalah sebesar Rp 168.8 milliar. Total tersebut dibagi dengan total kargo terkirim sehingga akan dihasilkan biaya satuan untuk skenario pengiriman direct adalah sebesar Rp 3,594/kg.

Tabel 13. Hasil Perhitungan Biaya Satuan Untuk Skenario Direct 


\begin{tabular}{|c|c|c|c|c|}
\hline Rute & $\begin{array}{c}\text { Total Biaya } \\
\text { (Jt-Rp/tahun) }\end{array}$ & $\begin{array}{c}\text { Biaya Satuan } \\
\text { (Rp/kg) }\end{array}$ & $\begin{array}{c}\text { Total Biaya Model } \\
\text { (Jt-Rp/tahun) }\end{array}$ & $\begin{array}{c}\text { Biaya Satuan Model } \\
\text { (Rp/kg) }\end{array}$ \\
\hline Rute 1 & 23,915 & 1,786 & & \\
Rute 5 & 23,379 & 3,964 & & \\
Rute 8 & 63,911 & 4,181 & 168,852 & 3,594 \\
Rute 9 & 45,519 & 4,194 & & \\
Rute 10 & 12,128 & 7,759 & & \\
\hline
\end{tabular}

2. Skenario Pengiriman Melalui Titik Hub PPS Kendari Berikut adalah skema yang dihasilkan oleh optimasi untuk skenario pengiriman melalui titik hub PPS Kendari:

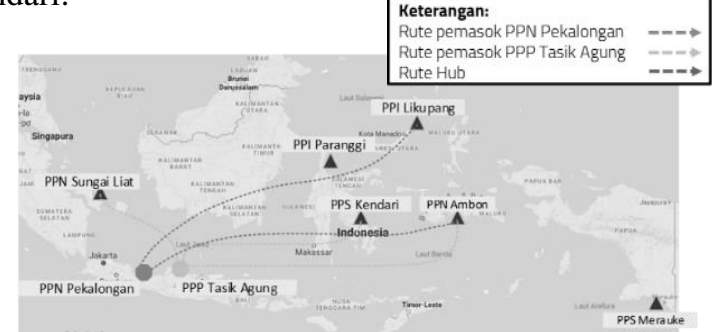

Gambar 12. Skema Pengiriman Melalui Titik Hub PPS Kendari.

Dari hasil optimasi tersebut dapat diketahui bahwa untuk rute dengan titik hub PPS Kendari, rute yang terpilih adalah Rute 1, Rute 3, Rute 4, Rute 5, dan Rute 7. PPN Sungai Liat (Kep. Bangka Belitung) akan memasok PPP Tasik Agung (Rembang) saja. Sedangkan PPI Paranggi (Sulawesi Tengah) dan PPS Merauke (Papua) tidak mengirimkan supply, karena pasokan supply telah dicukupi oleh PPS Kendari (Sulawesi Tenggara), PPN Ambon (Maluku) dan PPI Likupang (Sulawesi Utara).

Tabel 14. Rute Terpilih Untuk Skenario Pengiriman Titik $H u b$ PPS Kendari

\begin{tabular}{|c|l|l|c|c|c|}
\hline Rute & \multicolumn{1}{|c|}{ Asal } & \multicolumn{1}{|c|}{ Tujuan } & $\begin{array}{c}\text { Jarak } \\
(\mathrm{nm})\end{array}$ & $\begin{array}{c}\text { Kargo Terkirim } \\
\text { (ton) }\end{array}$ & $\begin{array}{c}\text { Frekuensi } \\
\text { (per tahun) }\end{array}$ \\
\hline Rute 1 & PPN Sungai Liat & PPP Tasik Agung & 437 & 13,389 & 48 \\
Rute 3 & PPS Kendari & PPP Tasik Agung & 1,019 & 16,750 & 60 \\
Rute 4 & PPS Kendari & PPN Pekalongan & 1,121 & 16,848 & 52 \\
Rute 5 & PPN Ambon & PPS Kendari & 593 & 21,570 & 67 \\
Rute 7 & PPI Likupang & PPS Kendari & 386 & 6,131 & 19 \\
\hline
\end{tabular}

Tabel 15. Kebutuhan Kapal Untuk Skenario Melalui Titik $H u b$ PPS Kendari

\begin{tabular}{|c|c|c|c|}
\hline Rute & Opsi Kapal & $\begin{array}{c}\text { Payload } \\
\text { (ton) }\end{array}$ & $\begin{array}{c}\text { Jumlah } \\
\text { (unit) }\end{array}$ \\
\hline Rute 1 & Kapal 4 & 309 & 1 \\
Rute 3 & Kapal 4 & 309 & 2 \\
Rute 4 & Kapal 5 & 359 & 2 \\
Rute 5 & Kapal 5 & 359 & 2 \\
Rute 7 & Kapal 5 & 359 & 1 \\
\hline
\end{tabular}

Dari hasil perhitungan waktu, Rute 3, yakni PPS Kendari - PPP Tasik Agung memiliki total waktu terpanjang, yakni 8.5 hari per roundtrip. Total waktu terpanjang kedua adalah Rute 4 dengan kebutuhan roundtrip 7.9 hari, dengan rute PPS Kendari - PPN Pekalongan. Total waktu terpendek adalah untuk Rute 7, yakni PPI Likupang - PPS Kendari, yakni 3.2 hari.

Tabel 16. Hasil Perhitungan Waktu Skenario Titik Hub PPS Kendari

\begin{tabular}{|c|c|c|}
\hline Rute & $\begin{array}{c}\text { Total Waktu } \\
\text { (hari/R.trip) }\end{array}$ & $\begin{array}{c}\text { Frekuensi Maksimal } \\
\text { (kali/tahun) }\end{array}$ \\
\hline Rute 1 & 4.1 & 73 \\
Rute 3 & 8.5 & 35 \\
Rute 4 & 7.9 & 37 \\
Rute 5 & 4.5 & 54 \\
Rute 7 & 3.2 & 94 \\
\hline
\end{tabular}

Dari keseluruhan biaya untuk masing-masing rute, total biaya yang timbul adalah sebesar Rp 200.5 milliar. Total tersebut dibagi dengan total kargo terkirim sehingga akan dihasilkan biaya satuan untuk skenario pengiriman melalui titik $h u b$ PPS Kendari adalah sebesar Rp 2,686/kg.

Tabel 17. Hasil Perhitungan Biaya Satuan Untuk Skenario $H u b$ PPS Kendari

\begin{tabular}{|c|c|c|c|c|}
\hline Rute & $\begin{array}{c}\text { Total Biaya } \\
\text { (Jt-Rp/tahun) }\end{array}$ & $\begin{array}{c}\text { Biaya Satuan } \\
\text { (Rp/kg) }\end{array}$ & $\begin{array}{c}\text { Total Biaya Model } \\
\text { (Jt-Rp/tahun) }\end{array}$ & $\begin{array}{c}\text { Biaya Satuan Model } \\
\text { (Rp/kg) }\end{array}$ \\
\hline Rute 1 & 23,916 & 1,786 & & \\
Rute 3 & 59,845 & 3,573 & & \\
Rute 4 & 57,513 & 3,414 & 200,584 & 2,686 \\
Rute 5 & 45,583 & 2,113 & & \\
Rute 7 & 13,728 & 2,239 & & \\
\hline
\end{tabular}

3. Skenario Pengiriman Melalui Titik Hub PPN Ambon Berikut adalah skema yang dihasilkan oleh optimasi untuk skenario pengiriman melalui titik hub PPN Ambon:

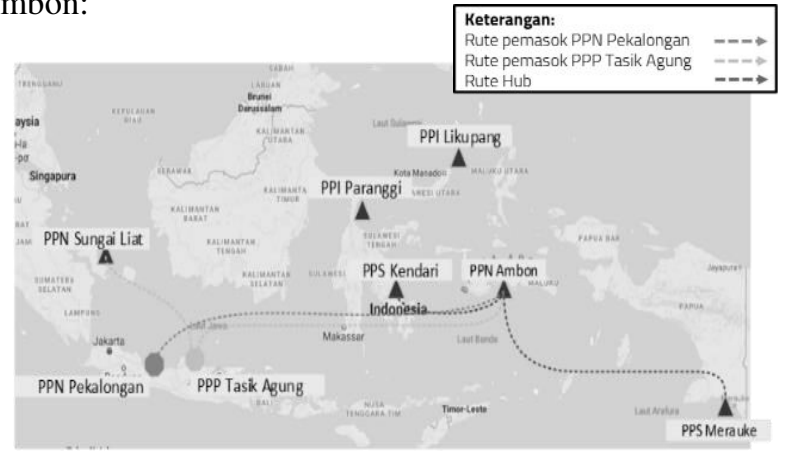

Gambar 13. Skema Pengiriman Skena Melalui Titik Hub PPN Ambon.

Untuk skenario pengiriman melalui titik hub PPN Ambon, terdapat 5 (lima) rute yang terpilih, yakni Rute 1, Rute 3, Rute 4, Rute 5 dan Rute 8. PPN Sungai Liat (Kep. Bangka Belitung) akan memasok PPP Tasik Agung (Rembang) saja, dengan frekuensi 48 kali per tahun. PPI Paranggi (Sulawesi Tengah) dan PPI Likupang (Sulawesi Utara) tidak terpilih menjadi titik supply, karena pasokan telah tercukupi.

Tabel 18. Rute Terpilih Untuk Pengiriman Melalui Titik $H u b$ PPN Ambon

\begin{tabular}{|c|l|l|c|c|c|}
\hline Rute & \multicolumn{1}{|c|}{ Asal } & \multicolumn{1}{|c|}{ Tujuan } & $\begin{array}{c}\text { Jarak } \\
(\mathrm{nm})\end{array}$ & $\begin{array}{c}\text { Kargo Terkirim } \\
\text { (ton) }\end{array}$ & $\begin{array}{c}\text { Frekuensi } \\
\text { (per tahun) }\end{array}$ \\
\hline Rute 1 & PPN Sungai Liat & PPP Tasik Agung & 437 & 13,389 & 48 \\
Rute 3 & PPN Ambon & PPP Tasik Agung & 1,068 & 16,750 & 60 \\
Rute 4 & PPN Ambon & PPN Pekalongan & 1,171 & 16,848 & 52 \\
Rute 5 & PPS Kendari & PPN Ambon & 593 & 5,317 & 16 \\
Rute 8 & PPS Merauke & PPN Ambon & 544 & 6,711 & 21 \\
\hline
\end{tabular}

Tabel 19. Kebutuhan Kapal Untuk Skenario Melalui Titik

\begin{tabular}{|l|c|c|c|}
\multicolumn{4}{|c}{ Hub PPN Ambon } \\
\hline Rute & Opsi Kapal & $\begin{array}{c}\text { Payload } \\
\text { (ton) }\end{array}$ & $\begin{array}{c}\text { Jumlah } \\
\text { (unit) }\end{array}$ \\
\hline Rute 1 & Kapal 4 & 309 & 1 \\
Rute 3 & Kapal 4 & 309 & 3 \\
Rute 4 & Kapal 5 & 359 & 2 \\
Rute 5 & Kapal 5 & 359 & 1 \\
Rute 8 & Kapal 5 & 359 & 1 \\
\hline
\end{tabular}

Dari hasil perhitungan waktu diatas, diketahui bahwa Rute 3, yakni PPN Ambon - PPP Tasik Agung memiliki total waktu terbesar, yakni 8.8 hari per roundtrip. Total waktu terbesar kedua adalah Rute 4 dengan kebutuhan roundtrip 8.2 hari, dengan rute PPN Ambon - PPN Pekalongan. Total waktu terpendek adalah untuk Rute 1, yakni PPN Sungai Liat - PPP Tasik Agung, dengan 4.1 hari/roundtrip. 
Tabel 20. Perhitungan Waktu Skenario Melalui Titik

\begin{tabular}{|c|c|c|}
\multicolumn{2}{c}{ Hub PPN Ambon } \\
\hline Rute & $\begin{array}{c}\text { Total Waktu } \\
\text { (hari/R.trip) }\end{array}$ & $\begin{array}{c}\text { Frekuensi Maksimal } \\
\text { (kali/tahun) }\end{array}$ \\
\hline Rute 1 & 4.1 & 73 \\
Rute 3 & 8.8 & 27 \\
Rute 4 & 8.2 & 30 \\
Rute 5 & 4.5 & 54 \\
Rute 8 & 4.2 & 58 \\
\hline
\end{tabular}

Dari keseluruhan biaya untuk masing-masing rute, total biaya yang timbul adalah sebesar Rp 183.9 milliar. Total tersebut dibagi dengan total kargo terkirim sehingga akan dihasilkan biaya satuan untuk skenario pengiriman melalui titik $h u b$ PPS Kendari adalah sebesar Rp 3,117/kg.

Tabel 21. Hasil Perhitungan Biaya Satuan Untuk Skenario Hub PPN Ambon

\begin{tabular}{|c|c|c|c|c|}
\hline Rute & $\begin{array}{c}\text { Total Biaya } \\
\text { (Jt-Rp/tahun) }\end{array}$ & $\begin{array}{c}\text { Biaya Satuan } \\
\text { (Rp/kg) }\end{array}$ & $\begin{array}{c}\text { Total Biaya Model Biaya Satuan Model } \\
\text { (Jt-Rp/tahun) } \\
\text { (Rp/kg) }\end{array}$ \\
\hline Rute 1 & 23,916 & 1,786 & & \\
Rute 3 & 68,920 & 4,115 & & 3,117 \\
Rute 4 & 59,291 & 3,519 & 183,965 & \\
Rute 5 & 15,313 & 2,880 & & \\
Rute 8 & 16,524 & 2,462 & & \\
\hline
\end{tabular}

\section{G. Perhitungan Biaya Transportasi Darat}

Alat angkut yang digunakan untuk transportasi darat adalah truk tronton reefer. Truk tersebut memiliki boks dengan ukuran panjang $630 \mathrm{~cm}$, lebar $220 \mathrm{~cm}$, dan tinggi $230 \mathrm{~cm}$. Dalam truk tersebut, ikan akan dimuat terlebih dahulu ke dalam bak fiber dengan ukuran panjang 100 $\mathrm{cm}$, lebar $60 \mathrm{~cm}$, tinggi $40 \mathrm{~cm}$. Untuk sekali pengiriman truk dapat memuat ikan sebanyak 14.4 ton. Berikut adalah ilustrasi truk refeer dan boks yang digunakan:
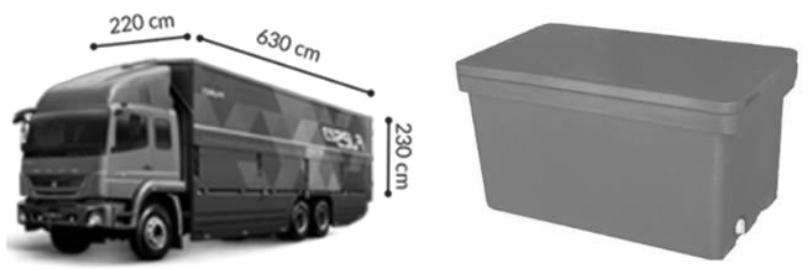

Gambar 14. Ilustrasi Truk dan Bak yang Digunakan.

Untuk perhitungan biaya transportasi darat, biaya dikelompokkan dalam 2 (dua) jenis biaya, yakni fixed cost dan variable cost. Fixed cost meliputi biaya sewa truk dan sewa sopir dan variable cost meliputi biaya bahan bakar dan biaya masuk pelabuhan.

\begin{tabular}{|c|c|c|c|}
\hline \multirow{2}{*}{ Pelabuhan } & \multirow{2}{*}{ Pabrik } & \multicolumn{2}{|c|}{$\begin{array}{l}\text { Fixed Cost } \\
\end{array}$} \\
\hline & & Tarif Sewa Truk* (Rp/hari) B & Biaya Sewa Sopir (Rp/hari) \\
\hline PPP Tasik Agung & PT. Bintang Karya Laut & \begin{tabular}{|l|l}
$12,250,000$ & \\
\end{tabular} & $1,050,000$ \\
\hline PPP Tasik Agung & cV. Sinar Mutiara Abadi & $3,500,000$ & 300,000 \\
\hline PPP Tasik Agung & PT. Holi Mina Jaya & $12,250,000$ & $1,050,000$ \\
\hline PPN Pekalongan & PT. Sinar Bahari Agung & $21,000,000$ & $1,800,000$ \\
\hline PPN Pekalongan & PT. Blue Sea Industry & $3,500,000$ & 300,000 \\
\hline \multirow{2}{*}{ Pelabuhan } & \multirow{2}{*}{ Pabrik } & \multicolumn{2}{|c|}{\begin{tabular}{|l} 
Variable Cost \\
\end{tabular}} \\
\hline & & Konsumsi BBM (Rp/R.trip) & Biaya Masuk Pelb (Rp) \\
\hline PpP Tasik Agung & PT. Bintang Karya Laut & $1,160,467$ & 300,000 \\
\hline PPP Tasik Agung & CV. Sinar Mutiara Abadi & 127,033 & 300,000 \\
\hline PPP Tasik Agung & PT. Holi Mina Jaya & 988,800 & 300,000 \\
\hline PPN Pekalongan & PT. Sinar Bahari Agung & $3,529,810$ & 345,000 \\
\hline PPN Pekalongan & PT. Blue Sea Industry & 59,225 & 345,000 \\
\hline Pelabuhan & Pabrik & Total (Rp/Pengiriman) & Biaya Satuan (Rp/kg) \\
\hline PPP Tasik Agung & PT. Bintang Karya Laut & $14,760,467$ & 1,025 \\
\hline PPP Tasik Agung & CV. Sinar Mutiara Abadi & $4,227,033$ & 294 \\
\hline PPP Tasik Agung & PT. Holi Mina Jaya & $14,588,800$ & 1,013 \\
\hline PPN Pekalongan & PT. Sinar Bahari Agung & $26,674,810$ & 1,852 \\
\hline PPN Pekalongan & PT. Blue Sea Industry & $4,204,225$ & 292 \\
\hline
\end{tabular}

\section{H. Perhitungan Biaya Transportasi Laut Terhadap Biaya Produksi}

Pengadaan bahan baku surimi dari wilayah lain tentunya akan menimbulkan komponen biaya baru, yakni biaya transportasi. Berikut adalah biaya transportasi untuk masing-masing pabrik:

Tabel 23. Biaya Transportasi Untuk Masing-Masing UPI

\begin{tabular}{|l|c|c|c|}
\hline \multicolumn{1}{|c|}{ Pabrik } & $\begin{array}{c}\text { Biaya Transportasi } \\
\text { Laut (Rp/kg) }\end{array}$ & $\begin{array}{c}\text { Biaya Transportasi } \\
\text { Darat (Rp/kg) }\end{array}$ & $\begin{array}{c}\text { Biaya Transportasi } \\
\text { (Rp/kg) }\end{array}$ \\
\hline PT. Bintang Karya Laut & 3,080 & 1,025 & 4,105 \\
\hline CV. Sinar Mutiara Abadi & 3,080 & 294 & 3,373 \\
\hline PT. Holi Mina Jaya & 3,080 & 1,013 & 4,093 \\
\hline PT. Sinar Bahari Agung & 4,513 & 1,852 & 6,366 \\
\hline PT. Blue Sea Industry & 4,513 & 292 & 4,805 \\
\hline
\end{tabular}

Untuk dapat mengetahui bagaimana pengaruh timbulnya biaya transportasi tersebut terhadap biaya produksi industri surimi, berikut adalah komponen biaya produksi surimi [8]:

\begin{tabular}{cc}
\multicolumn{2}{c}{ Tabel 24. Komponen Biaya Produksi Surimi } \\
\hline \multicolumn{1}{c}{ Item } & Nilai \\
\hline Biaya Produksi & $100 \%$ \\
\hline Persentase Fixed Cost & $29 \%$ \\
\hline Persentase Variable Cost & $71 \%$ \\
\hline Pengadaan BB : Variable Cost & $90 \%$ \\
\hline
\end{tabular}

Tabel 25. Perbandingan Biaya Produksi Berdasarkan Bahan Baku

\begin{tabular}{lccc}
\hline \multirow{2}{*}{ Item } & \multirow{2}{*}{ Satuan } & \multicolumn{2}{c}{ Biaya Berdasarkan Bahan Baku } \\
\cline { 3 - 4 } & & Ikan Eksisting & Ikan Pengganti \\
\hline Harga Surimi & $R p / k g$ & $\mathbf{3 7 , 1 2 5}$ & $\mathbf{3 7 , 1 2 5}$ \\
\hline Biaya Bahan Baku & $R p$ & 6,000 & 19,971 \\
\hline & $R p / k g$ & 20,800 & 62,310 \\
\hline Variable Cost & $\boldsymbol{R p} / \mathbf{k g}$ & $\mathbf{2 9 , 2 9 6}$ & $\mathbf{9 7 , 5 1 1}$ \\
\hline Total Cost & $\boldsymbol{R p} / \mathbf{k g}$ & $\mathbf{7 , 8 2 9}$ & $\mathbf{- 6 0 , 3 8 6}$ \\
\hline Margin Keuntungan & & $\mathbf{2 7 \%}$ & $\mathbf{- 6 2 \%}$ \\
\hline
\end{tabular}

Perbandingan biaya produksi surimi dengan menggunakan bahan baku ikan eksisiting dan dengan bahan baku pengganti dapat dilihat pada Tabel 25:

Dari hasil analisis di atas, pembuatan surimi menggunakan bahan baku ikan tenggiri dengan asumsi harga surimi tidak berubah, maka industri surimi akan mengalami kerugian. Padahal angka tersebut belum ditambahkan dengan biaya transportasi. Jika bahan baku yang digunakan adalah tetap, yakni ikan demersal, maka berikut analisis mengenai pengaruh biaya transportasi terhadap biaya produksi:

Tabel 26. Pengaruh Biaya Transportasi Terhadap Biaya Produksi Surimi

\begin{tabular}{lcc}
\hline \multicolumn{1}{c}{ Item } & Satuan & Nilai \\
\hline Biaya Bahan Baku & $R p / k g$ & 6,000 \\
\hline Variable Cost & $R p$ & 18,720 \\
\hline Total Cost & $R p / k g$ & 20,800 \\
\hline Biaya Transportasi & $\mathbf{R p} / \mathbf{k g}$ & $\mathbf{2 9 , 2 9 6}$ \\
\hline Biaya Transportasi Laut & $\mathbf{R p} / \mathbf{k g}$ & $\mathbf{4 , 5 3 8}$ \\
\hline Biaya Transportasi Darat & $\mathrm{Rp} / \mathrm{kg}$ & 2,686 \\
\hline Persentase Biaya Transportasi & $\mathrm{Rp} / \mathrm{kg}$ & 1,852 \\
\hline Total Cost + Biaya Transportasi & $\mathbf{R p} / \mathbf{k g}$ & $\mathbf{1 5 \%}$ \\
\hline
\end{tabular}

Dari Tabel 26, dapat diketahui bahwa, biaya transportasi menambah total biaya sebesar $15 \%$. Biaya produksi yang sebelumnya Rp 29,296 per kg naik menjadi Rp 33,834 per kg.

\section{Analisis Sensitivitas}

1. Pengaruh Tingkat Kerusakan Ikan Terhadap Biaya Satuan 
Kemungkinan ikan busuk atau rusak dalam pengiriman, tidak dapat dihindari. Salah satu cara untuk menanggulangi risiko tersebut adalah dengan menambah pasokan. Dalam analisis yang telah dilakukan, penambahan pasokan diasumsikan sama dengan tingkat kerusakan, semisal jika tingkat kerusakan sebesar 2.5\%, maka pasokan juga akan ditambah sebesar $2.5 \%$. Hasil yang didapatkan, semakin tinggi tingkat kerusakan, biaya satuan juga akan semakin tinggi. Hal ini disebabkan karena semakin banyak pasokan yang dikirim, total biaya yang timbul juga akan semakin banyak. Berikut adalah grafik yang dihasilkan dalam analisis ini:

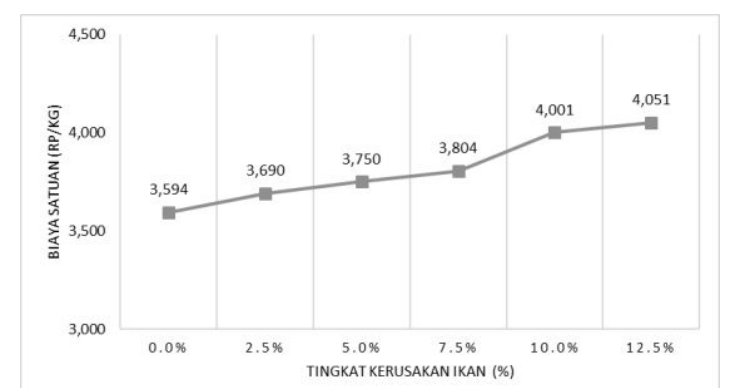

Gambar 15. Pengaruh Tingkat Kerusakan Ikan dengan Biaya Satuan

2. Pengaruh Tingkat Kenaikan Harga Bahan Baku terhadap Margin Keuntungan

Harga bahan baku yang digunakan dalam analisis ini adalah harga rata-rata bahan baku ikan demersal, yakni Rp 6.000 per kg. Diasumsikan kenaikan harga bahan baku setiap $20 \%$ dengan kenaikan maksimum yakni 150\%. Dari hasil grafik di atas, disimpulkan bahwa margin keuntungan akan habis (pabrik tidak untung) jika harga bahan baku melonjak hingga $130 \%$ atau sebesar Rp 7.800 per $\mathrm{kg}$ menjadi $\mathrm{Rp} 13.800$ per $\mathrm{kg}$, dan akan mengalami kerugian jika bahan baku melonjak hingga 150\% atau sebesar Rp 9.000 per kg menjadi Rp 15.000 per $\mathrm{kg}$.

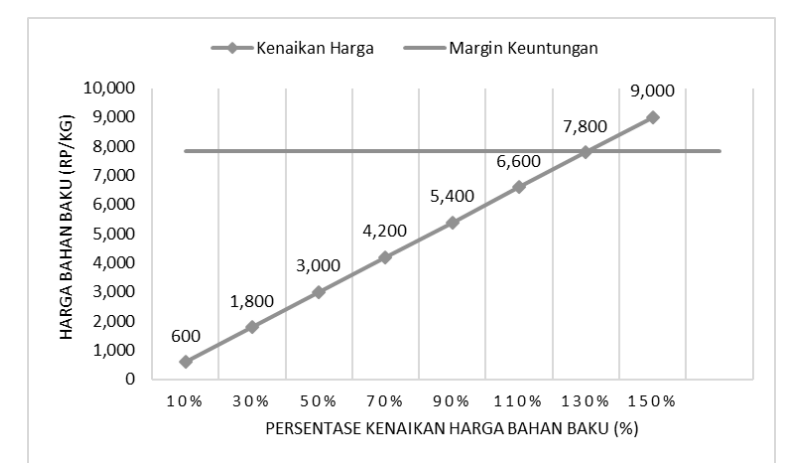

Gambar 16. Pengaruh Kenaikan Harga Bahan Baku terhadap Margin Keuntungan.

\section{KESIMPULAN}

Dari analisis yang telah dilakukan, maka diperoleh beberapa kesimpulan, antara lain:

1. Karakteristik untuk bahan baku surimi adalah ikan berkadar lemak rendah dengan konsistensi daging yang padat dan kandungan protein yang tinggi agar dihasilkan surimi dengan sifat gel yang baik. Jenis ikan demersal (kurisi, tigawaja, beloso), ikan tenggiri, ikan kakap, ikan lele dumbo dapat dipakai sebagai bahan baku surimi

2. Lokasi pemasok alternatif bahan baku surimi yakni ikan Tenggiri, Kakap Merah, Tigawaja, dan Beloso berlokasi di 6 (enam) provinsi, yakni Bangka Belitung (13.389 ton/tahun), Sulawesi Utara (15.285 ton/tahun), Sulawesi Tengah (6.723 ton/tahun), Sulawesi Tenggara (5.898 ton/tahun), Maluku (21.570 ton/tahun) dan Papua (6.711 ton/tahun)

3. Model skenario pengiriman melalui titik $h u b$ PPS Kendari memiliki biaya satuan yang paling rendah yakni Rp. 2.686 per $\mathrm{kg}$. 5 rute yang terpilih dalam model tersebut antara lain, Rute 1 PPN Sungai Liat - PPP Tasik Agung dengan kargo ikan terkirim 13.389 ton/tahun, Rute 3 PPS Kendari - PPP Tasik Agung (16.750 ton/tahun), Rute 4 PPS Kendari - PPN Pekalongan (16.848 ton/tahun), Rute 5 PPN Ambon - PPS Kendari (21.570 ton/tahun), dan Rute 7 PPI Likupang - PPS Kendari (6.131 ton/tahun).

4. Penambahan biaya transportasi untuk produksi surimi dengan bahan baku eksisting yakni ikan demersal, menambah biaya produksi sebesar $15 \%$. Pabrik surimi akan merugi jika kenaikan harga bahan baku mencapai $130 \%$ dari harga bahan baku sekarang.

\section{DAFTAR PUSTAKA}

[1] Kementerian Kelautan dan Perikanan, "Produktivitas Perikanan Indonesia," Jakarta, 2017.

[2] Dirjen Perikanan Tangkap KKP, "Dukungan DJTP Terhadap Keberlangsungan Industri Surimi," Semarang, 2018.

[3] I. Rostini, "Pemanfaatan Daging Lembah Fillet Ikan Kakap Merah Sebagai Bahan Baku Surimi untuk Produk Perikanan,” J. Akuatika, pp. 2-3, 2013.

[4] R. Adawyah, Pengolahan dan Pengawetan Ikan. Jakarta: Bumi Aksara, 2007.

[5] Diyantoro, "Pengaruh Lama Penyimpanan Yang Berbeda DalamCampuran Air Laut Dan Es Terhadap Kemunduran Mutu Kesegaran Ikan Nila (Oreochromissp.),”Jul. 2008.

[6] B. Wibowo, "Garis Besar Rancangan Pengembangan Industri Surimi Indonesia.” Jakarta, 2018.

[7] N. Djazuli, M. Wahyuni, D. Monintja, and A. Purbayanto, "Modifikasi Teknologi Pengolahan Surimi Dalam Pemanfaatan 'By Catch' Pukat Udang di Laut Arafura," J. Pengolah. Has. Perikan. Indones., pp. 24-25, 2009.

[8] Diana Wulandari, "Pengolahan Surimi Beku di UD. Anela, Lamongan Jawa Timur,” 2016. 